\title{
Cryptic Intragenic Deletion of the SHOX Gene in a Family with Léri-Weill Dyschondrosteosis Detected by Multiplex Ligation-Dependent Probe Amplification (MLPA)
}

\section{perspectives}

\author{
Mariana F. A. FunarI \\ AleXANDER A. L. JoRge \\ EMILIA M. PINTO \\ IVO J. P. ARNHOLD \\ BeRENICE B. MENDONCA
}

MIRIAN Y. NISHI

Laboratório de Hormônios e Genética Molecular LIM/42, Unidade de Endocrinologia do Desenvolvimento, Hospital das Clínicas da Faculdade de Medicina da Universidade de São Paulo (HC-FMUSP), São Paulo, SP, Brasil.

Received in 25/8/2008

Accepted in 2/10/2008

\section{ABSTRACT}

LWD is associated to SHOX haploinsufficiency, in most cases, due to gene deletion. Generally FISH and microsatellite analysis are used to identify SHOX deletion. MLPA is a new method of detecting gene copy variation, allowing simultaneous analysis of several regions. Here we describe the presence of a SHOX intragenic deletion in a family with LWD, analyzed through different methodologies. Genomic DNA of 11 subjects from one family were studied by microsatellite analysis, direct sequencing and MLPA. FISH was performed in two affected individuals. Microsatellite analysis showed that all affected members shared the same haplotype suggesting the involvement of SHOX. MLPA detected an intragenic deletion involving exons IV-VIa, which was not detected by FISH and microsatellite analysis. In conclusion, the MLPA technique was proved to be the best solution on detecting this small deletion, it has the advantage of being less laborious also allowing the analysis of several regions simultaneously. (Arq Bras Endocrinol Metab 2008; 52/8:1382-1387)

Keywords: Léri-Weill Dyschondrosteosis, SHOX, intragenic deletion, MLPA

\section{RESUMO}

\begin{abstract}
Deleção Críptica Intragênica do Gene SHOX em uma Família com Discondrosteose de Léri-Weill Detectada por Multiplex Ligation-Dependent Probe Amplification (MLPA).
\end{abstract}

Discondrosteose de Léri-Weill (DLW) está associada à haploinsuficiência do gene SHOX resultante, principalmente, de deleções. Geralmente, o FISH e a análise de microssatélites são os métodos utilizados para a identificação destas deleções. MLPA é um novo método para detectar variações do número de cópias gênicas, permitindo uma análise simultânea de várias regiões. Aqui, descrevemos uma pequena deleção intragênica no SHOX em uma família com DLW analisada por diferentes metodologias. DNA genômico de $11 \mathrm{mem}-$ bros de uma família foram estudados por microssatélites, seqüenciamento direto e MLPA. FISH foi realizado em dois indivíduos afetados. Os microssatélites demonstraram que todos os membros afetados apresentavam o mesmo haplotipo, sugerindo o envolvimento do SHOX. MLPA identificou uma deleção intragênica envolvendo os éxons IV-Vla, que não foi detectada pelo FISH e pelos microssatélites. Conclui-se que o MLPA demonstrou melhor resolução para detectar esta pequena deleção, com a vantagem de ser menos trabalhoso e permitir a análise de várias regiões simultaneamente. (Arq Bras Endocrinol Metab 2008; 52/8:1382-1387)

Descritores: Discondrosteose de Léri-Weill; SHOX; Deleção intragênica; MLPA 


\section{INTRODUCTION}

n 1997, two independent groups identified a gene related to stature $(1,2)$ : short stature homeobox containing gene (SHOX) [MIM 312865], located within the pseudoautosomal region 1 (PAR 1 ) of the short arms of sex chromosomes. They found it to be composed of 7 exons and having about $40 \mathrm{~Kb}(3)$.

This gene belongs to a family of genes that encode a cell-specific homeodomain protein of the paired like type involved in cell cycle and growth regulation (4). This protein, expressed in high levels in osteogenic cells, binds to DNA in a sequence-specific manner and acts as a transcriptional activator, regulating the expression of others genes also involved in growth process (4). SHOX protein may also function as a repressor of chondrocytes differentiation within the growth plate, then $S H O X$ haploinsufficiency may result in premature terminal differentiation of proliferative chondrocytes, with progression to the hypertrophic phenotype and accelerated growth plate fusion (5).

SHOX haploinsufficiency is associated to Turnerlike phenotype, Léri-Weill dyschondrosteosis (LWD) and also idiopathic short stature. LWD [MIM 127300] is a dominant inherited skeletal dysplasia characterized by disproportionate short stature, mesomelic limb shortening and the Madelung deformity of the forearm, with bowing of the radius and dorsal dislocation of the distal ulna (6). The genotype-phenotype correlation is weak and incomplete expression in families with LWD has been demonstrated, with some patients carring SHOX mutations, only presenting short stature without the Madelung deformity (7). Heterozygous defects in SHOX have been identified in 56-100\% of LWD cases. Variability in the detection rates can often be explained by differences in cohort composition, clinical criteria or mutation detecting methods (7).

About two thirds of SHOX gene defects are caused by deletions (8). Fluorescence in situ hybridization (FISH) technique, microsatellite analysis and Southern blotting are the most common techniques used to identify these deletions. Recently, a new methodology was developed to detect gene copy variation, the Multiplex Ligation-Dependent Probe Amplification (MLPA). It is based on the simultaneous hybridization of several probes followed by a multiplex PCR amplification. In one reaction, different regions within and around the gene are analyzed (9).
In the present study, we describe the presence of SHOX intragenic deletion in a family with LWD, evaluated through several distinct molecular strategies including MLPA technique.

\section{SUBJECTS AND METHODS}

\section{Patients}

This study was approved by the Ethics Committee of the Hospital das Clinicas of the University of Sao Paulo Medical School, University of Sao Paulo. The patients or tutors gave their written informed consent.

The index case is an apparently healthy Brazilian girl of mixed ethnicity, with short stature noticed by her parents at 6 years of age. She was born at term by vaginal delivery after an uneventful pregnancy, with normal birth weight $(3,600 \mathrm{~g})$. She is the first child of nonconsanguineous parents. Both parents are short, her father's height is $159 \mathrm{~cm}(-2.4 \mathrm{SD})$ and her mother's height is $149 \mathrm{~cm}(-2.2 \mathrm{SD})$. The patient was referred to our hospital at 11 years of age. At that time, she was prepubertal and presented with short stature (height standard deviation score $[S D S]=-3.4$ ) and normal weight (body mass index SDS = 0.6). Physical examination disclosed a high arched palate, cubitus valgus, disproportional body proportion with short limbs (sitting height:height for age SDS $=+4.5$ ) and mesomelia (upper and lower arm length SDS of -4.7 and -5.5 , respectively). No Madelung or other skeletal deformity was observed in the patient and in her first-degree relatives. Her father was not available for better phenotype characterization. However, a careful review of her family history identified 1 aunt and 2 second-degree relatives (Figure 1) from paternal side with disproportionate short stature and Madelung deformity (Figure 2), findings that indicated Léri-Weill dyschondrosteosis.

Results of routine laboratory assessments and hormonal measurement were normal. Patient's bone age was of a 11 year-old and no radiology signal of Madelung deformity was observed.

\section{Cytogenetic analysis}

Chromosome analysis was performed on chromosomal spreads obtained from peripheral blood lymphocyte cultures of the patients using standard karyotyping techniques with G-banding. FISH methodology was carried out in lymphocyte metaphase spreads, using 


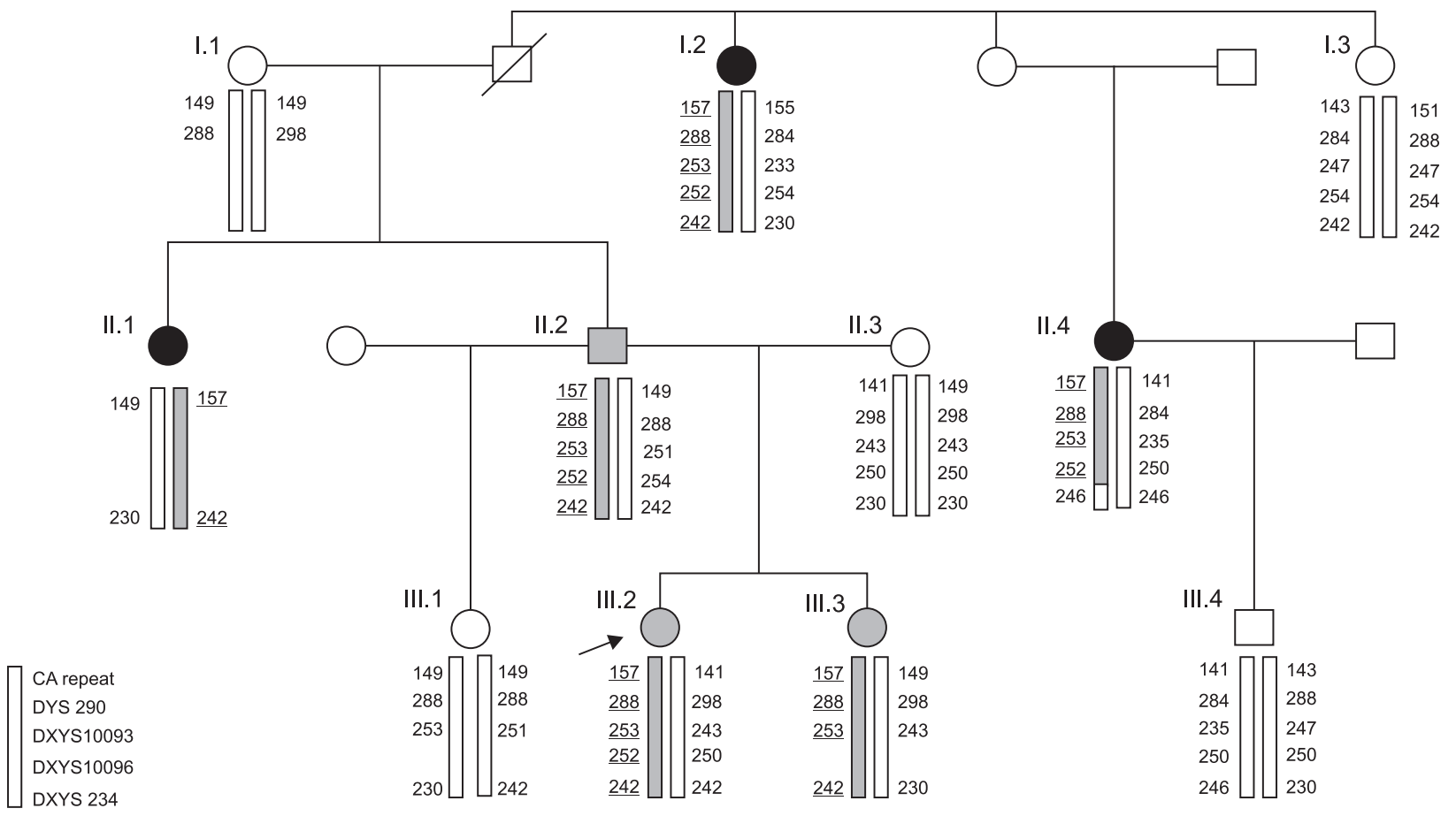

and

: Léri-Weill dyschondrosteosis

Figure 1. Family heredogram showing that all affected members shared the same haplotype suggesting the involvement of SHOX.

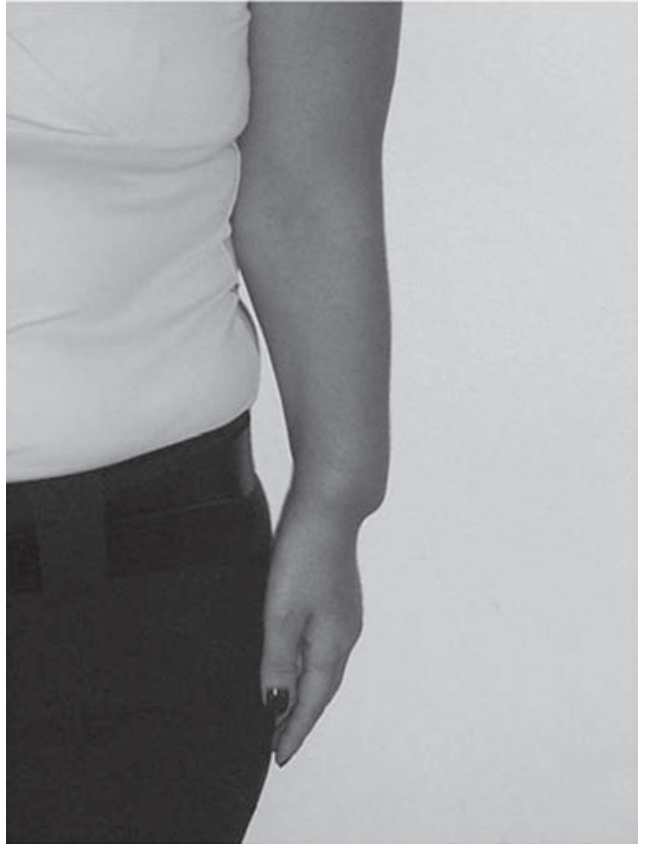

Figure 2. Madelung deformity in patient II.4. biotinylated cosmid LLNOYCO3' $\mathrm{M}^{\prime} 34 \mathrm{~F} 5$ as a probe, which contains exons III to VIb of SHOX (10). The analysis was performed using the Karyotyping Software Macktype v.5.4.1 and Mackprobe v. 4.0 (Perceptive Scientific Instruments Inc., UK).

\section{Molecular Analysis}

Genomic DNA was isolated from peripheral blood leukocytes using the salt precipitation method (11). For microsatellite analysis, the markers $S H O X$ CA repeat, DYS290, DXYS10093, DXYS10096 and DXYS234 were used. CA repeat is an intragenic marker identified in the 5' untranslated region of exon I. DYS290 and DXYS10093 are intragenic markers. DXYS10096 is 3' flanking the gene, located at an important region apparently implicated in etiopathogenesis of LWD (12). DXYS234 is located downstream of SHOX approximately $2 \mathrm{cM}$ from the Xp telomere (Figure 3 ). They were amplified from the family genomic DNA using fluorescent labeled primers. The PCR products were submitted to electrophoresis in the ABI PRISM 310 automatic 


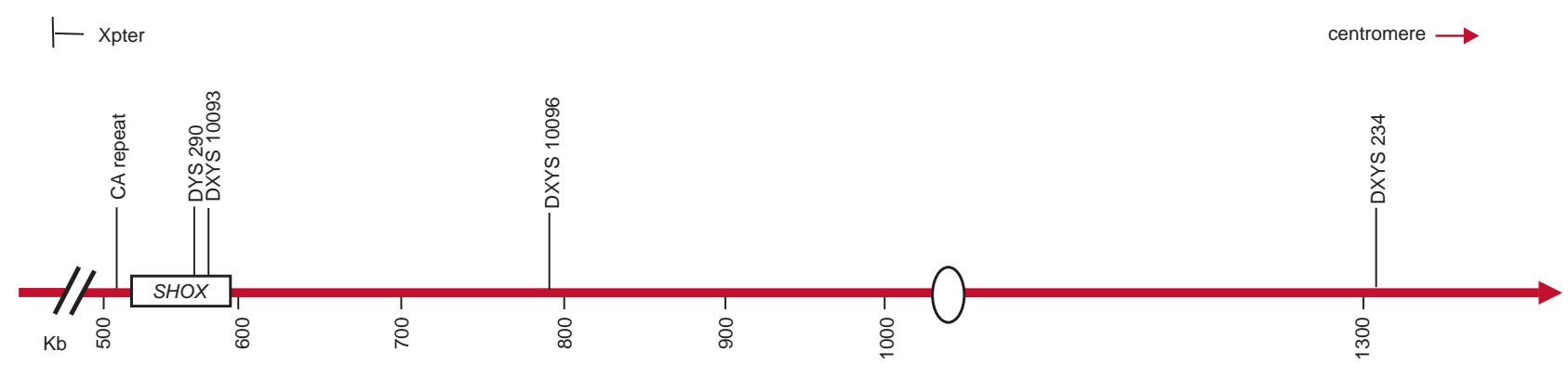

Figure 3. Schematic representation of microsatellite markers position on PAR 1 (Adapted from Benito-Sanz and cols. (12)).

sequencer (Applied Biosystems, Foster City, CA, USA) and the analysis was made by GeneScan software (Applied Biosystems, Foster City, CA, USA).

Genomic DNA was amplified by PCR and sequenced on an ABI PRISM 3100 (Applied Biosystems, Foster City, CA, USA) automatic sequencer using the fluorescent dideoxy-terminator method and specific intronic primers, previously described for exons II to VI of $\operatorname{SHOX}(13)$.

MLPA analysis of SHOX and PAR 1 region was carried out using the commercial Kit P018-Cl SHOX (MCR Holland, Amsterdam, The Netherlands). This kit contains 8 probes for $S H O X$ exons, 13 for $S H O X$ surround area and 13 for the other $\mathrm{X}$ regions. Six individuals with normal height and body proportions were used as control for PARI deletion. As deletion control, four individuals with SHOX deletion detected by FISH were used. The manufacturer instructions were followed and data was analyzed using Coffalyser software (MCR Holland, Amsterdam, The Netherlands).

\section{RESULTS}

The index case (III.2) and one second-degree relative (II.4) presented normal karyotype with presence of SHOX in FISH analysis (Figure 4).

Microsatellite analysis did not display any deletion. This analysis showed that all affected members (I.2, II.1, II.2, II.4, III.2 and III.3) shared the same haplotype (Figure 1). In the individuals I.2, I.3, III.2, III.4 the direct sequencing did not identify mutations in the encoding region and splicing sites.

An intragenic deletion of exons IV to VIa in heterozygous form was detected in 5 affected members (I.2, II.2, II.4, III.2 and III.3) by MLPA (Figure 5). It was not possible to perform MPLA analysis in the affected member II.l due to insufficient genomic DNA and the impossibility to obtain new sample.

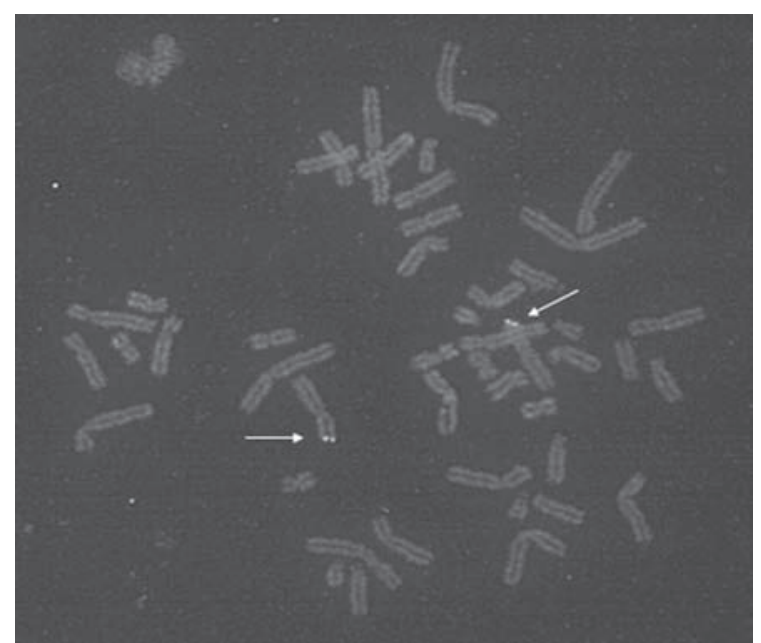

Figure 4. Fluorescence in situ hybridization of cosmid LLNOYCO3'M'34F5 to metaphase chromosome in the index case. Note the presence of two signals on Xp.

\section{DISCUSSION}

Several methodologies have been used in SHOX mutation screening, but the molecular defect remains unidentified in a significant proportion of LWD cases. Several factors can be involved in the failure to detect mutations in SHOX gene. First of all an alternative clinical diagnosis should be excluded. Secondly, the molecular defect may be present in unscreened areas of the SHOX gene (14).

SHOX gene deletion is the most common cause of LWD and it is usually detected by FISH or microsatellite analysis. However, in this family both techniques failed to detect the intragenic deletion which was detected by MLPA. FISH is a laborious and expensive technique that uses biotinylated specific probes and permits their visualization in a fluorescent microscope. In normal individuals with two copies of SHOX, two fluorescent signals are visible in each metaphase. In de- 


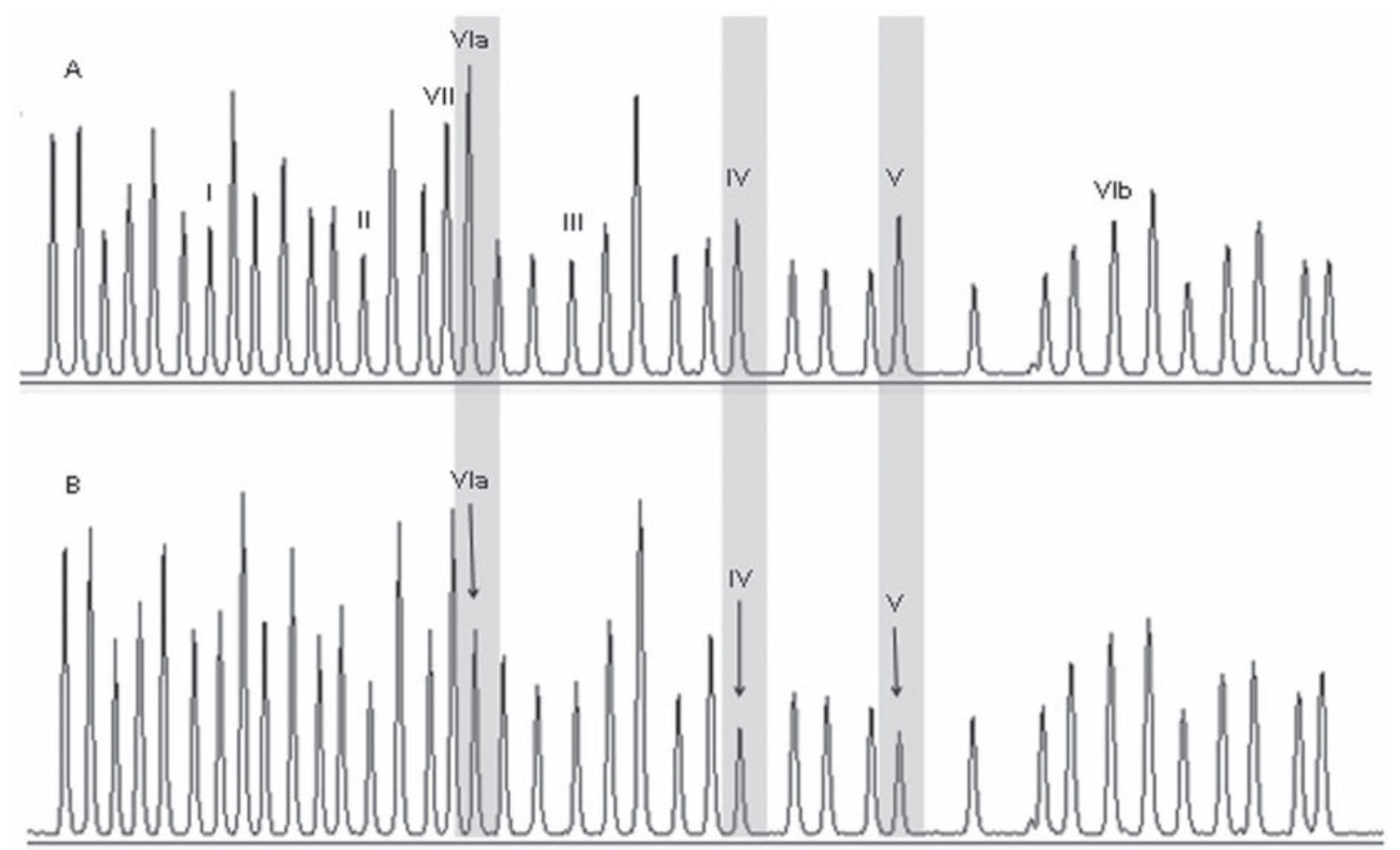

Figure 5. Electropherograms of MLPA runs. Each peak corresponds to amplification of one probe. A - Normal control. B - Index case: Comparisons of relative peak areas indicate heterozygous deletion involving exons IV, V and Vla.

letions of one copy, only one signal is visible. This methodology does not allow the detection of small deletions. In this family the clone LLNOYCO3"M"34F5 of $42 \mathrm{~Kb}$ hybridized to the SHOX gene, despite the presence of the small deletion.

Microsatellite analysis uses fluorescent primers and an automatic sequencer. This technique is able to detect small deletions but in case of big genes as SHOX, it is important to analyze several markers to cover the entire gene. Besides that, parents' DNA analysis is necessary to characterize the presence of small deletions. This analysis showed that all affected members shared the same haplotype indicating the involvement of SHOX region. However, since the markers were not located at the deleted region, it was not detected by microsatellite analysis. No mutation was detected in SHOX exons and splicing regions by direct sequencing. This family presented an apparently normal SHOX gene, despite the typical phenotype.

MLPA is a relatively simple technique that is commercially available for $S H O X$ analysis. In this family the MLPA detected a deletion involving exons IV to VIa in all affected members analyzed. Analyzing the probes and DYS290 marker positions, it was possible to estimate that deletion could be 4 to $14 \mathrm{~kb}$ in length.

It is noteworthy that microdeletions involving SHOX are much more prevalent than intragenic SHOX mutations (15). MLPA has been an important tool for the diagnosis of patients with SHOX microdeletions. Recently, Fukami and cols. reported three patients with LWD with apparently normal SHOX according to conventional screening techniques. MLPA also detected an heterozygous deletion involving exons IV and $\mathrm{V}$ in one case, exons IV-VIa in the second case and exons IVVIb in the third case (8).

In conclusion, MLPA technique for $S H O X$ analysis has the best resolution to detect small deletions and has the advantage to be less laborious and should be used to identify cryptic SHOX intragenic deletions.

Acknowledgment: This work was supported by grants from Fundacao de Amparo a Pesquisa do Estado de Sao Paulo - FAPESP (05/04726-0) and from Conselho Nacional de Desenvolvimento Cientifico e Tecnologico - CNPq (307951/06-5 to A.A.L.J., 301246/95-5 to B.B.M. and 300938/06-3 to I.J.P.A.) No other potential conflict of interest relevant to this article was reported. 


\section{REFERENCES}

1. Ellison JW, Wardak Z, Young MF, Gehron Robey P, Laig-Webster M, Chiong W. PHOG, a candidate gene for involvement in the short stature of Turner syndrome. Hum Mol Genet. 1997;6:1341-7.

2. Rao E, Weiss B, Fukami M, Rump A, Niesler B, Mertz A, et al. Pseudoautosomal deletions encompassing a novel homeobox gene cause growth failure in idiopathic short stature and Turner syndrome. Nat Genet. 1997;16:54-63.

3. Blaschke RJ, Rappold GA. SHOX: growth, Leri-Weill and Turner syndromes. Trends Endocrinol Meta.b 2000;11:227-230.

4. Rao E, Blaschke RJ, Marchini A, Niesler B, Burnett M, Rappold GA. The Leri-Weill and Turner syndrome homeobox gene SHOX encodes a cell-type specific transcriptional activator. Hum Mol Genet. 2001;10:3083-91.

5. Munns CJ, Haase HR, Crowther LM, Hayes MT, Blaschke R, Rappold G, et al. Expression of SHOX in human fetal and childhood growth plate. J Clin Endocrinol Metab. 2004;89:4130-5.

6. Belin V, Cusin V, Viot G, Girlich D, Toutain A, Moncla A, et al. SHOX mutations in dyschondrosteosis (Leri-Weill syndrome). Nat Genet. 1998; 19:67-9.

7. Jorge AA, Souza SC, Nishi MY, Billerbeck AE, Liborio DC, Kim $\mathrm{CA}$, et al. SHOX mutations in idiopathic short stature and LeriWeill dyschondrosteosis: frequency and phenotypic variability. Clin Endocrinol (Oxf). 2007;66:130-5.

8. Fukami M, Dateki S, Kato F, Hasegawa Y, Mochizuki H, Horikawa $\mathrm{R}$, et al. Identification and characterization of cryptic SHOX intragenic deletions in three Japanese patients with Leri-Weill dyschondrosteosis. J Hum Genet. 2008;53:454-9.

9. Schouten JP, McElgunn CJ, Waaijer R, Zwijnenburg D, Diepvens F, Pals G. Relative quantification of 40 nucleic acid sequences by multiplex ligation-dependent probe amplification. Nucleic Acids Res. 2002; 30:e57.
10. Flanagan SF, Munns CFJ, Hayes M, Williams B, Berry M, Vickers D, et al. Prevalence of mutations in the short stature homeobox containing gene (SHOX) in Madelung deformity of childhood. J Med Genet. 2002;39:758-63.

11. Miller SA, Dykes DD, Polesky KF. A simple salting out procedure for extracting DNA from human nucleated cells. Nuc Acid Res. 1998;16:1215.

12. Benito-Sanz $S$, Thomas NS, Huber $C$, Gorbenko del Blanco D, Aza Carmona, M, Crolla JA, et al. A novel class of pseudoautosomal region 1 deletions downstream of SHOX is associated with Léri-Weill dyschondrosteosis. Am Hum Genet. 2005;77: 533-44.

13. Shears DJ, Vassal HJ, Goodman FR, Palmer RW, Reardon W, Superti-Furga A, et al. Mutation and deletion of the pseudoautosomal gene SHOX cause Leri-Weill dyschondrosteosis. Nat Genet. 1998;19:70-3.

14. Jorge AA, Nishi MY, Funari MFA, Souza SC, Arnhold IJP Mendonça BB. Baixa estatura por haploinsuficiência do gene SHOX: do diagnostico ao tratamento. Arq Bras Endocrinol Metab. 2008;52(5):765-73.

15. Ogata T. SHOX haploinsufficiency: lessons from clinical studies. Endocrinology \& Diabetes. 2002;9(1):13-20.

\section{Correspondece to:}

Miriam Nishi

Hospital das Clínicas, FMUSP, Laboratório de Hormônios e Genética Molecular LIM 42 , Disciplina de Endocrinologia Av. Dr Enéias de Carvalho Aguiar, 155, PAMB, $2^{\circ}$ andar, bloco 6 05403-900 São Paulo, SP

E-mail: minishi@usp.br 